\title{
'Beat Your Plowshares into Swords and Your Pruninghooks into Spears': A Contextual Critique of Expulsion Decisions and Appeal Rights in the United Kingdom
}

\author{
Cosmas Ukachukwu Ikegwuruka ${ }^{1}$, Linus Chukwuemeka Okere ${ }^{2}$ \\ ${ }^{1}$ Almond Legals-Immigration, Asylum and Human Rights Lawyers \& Researchers, London, UK \\ ${ }^{2}$ Centre for Global Media and Communications, School of Oriental and African Studies (University of London), London, UK
}

Email address:

almondlegals@yahoo.co.uk (C. U. Ikegwuruka),lo18@soas.ac.uk (L. C. Okere)

\section{To cite this article:}

Cosmas Ukachukwu Ikegwuruka, Linus Chukwuemeka Okere. 'Beat Your Plowshares into Swords and Your Pruninghooks into Spears': A Contextual Critique of Expulsion Decisions and Appeal Rights in the United Kingdom. International Journal of Law and Society. Special Issue: Immigration Control, Citizenship, the Interplay of Sovereignty and the Vicissitudes of the Hostile Environment.

Vol. 3, No. 2, 2020, pp. 39-46. doi: 10.11648/j.ijls.20200302.11

Received: February 13, 2020; Accepted: March 11, 2020; Published: May 12, 2020

\begin{abstract}
The putative question is whether the United Kingdom complies with its treaty obligations under International Human Rights Law (IHRL) in the expulsion of migrants? The debate is that expulsion laws as they stand may have been contrived to enhance deportability or removability. It is further argued that the ever increasing and shifting pattern of deportation laws (some of which are retroactive) appears to violate the basic principles of human rights norms. This is heightened by the fact that these laws are either discretionary or couched in rigid terms leaving less chance for compassionate considerations even in the light of unclear judicial interpretation given to some of these expulsion laws. Although, States are afforded some discretion as to the manner in which they conform to their obligations under IHRL, that discretion, however, must not result in the practical denial of the minimum procedural safeguards needed to protect the migrant against arbitrary expulsion. By certifying decisions regarding expulsion, the paper finds that the State $a b$ initio creates the amphitheater for expulsion of migrants. The argument is that the dichotomy between an 'immigration decision' and 'non-immigration decision' is a false one as it is probably anchored with the apparent intention of achieving expulsion of migrants from the UK in an ostensibly hostile environment. It is curious that the irregular migrant who makes an application (usually by payment of a fee) to the Home Office to regularize his stay which was eventually refused will not be accorded a right of appeal simply because, the State sees such applications as not befitting of a right of appeal. It is therefore difficult to justify the rationale to deny a right of appeal to a migrant or to dichotomize between an immigration decision and a non-immigration decision in the light of the immigration rules. The doctrinal methodology is applied in this paper.
\end{abstract}

Keywords: Expulsion, Deportation, Removal, Certification, Immigration Decision, Appeals, Suspensivity and Equality of Arms

\section{Introduction}

Expulsion (deportation or removal) aims to enforce the departure of the migrant out of the State. This lends credence to the argument that deportation and or removal have become integral and key aspects of immigration control [1]. It is unarguable however that with the advent, emergence and development of regional and global human rights institutions, States by virtue of their treaty obligations incumbent on these developments have ceded a measure of their sovereignty [2].
In essence, the emergence of the ECHR characterized as an international human rights treaty with regional compass becomes germane [3] given that freedoms enumerated in the ECHR are resultantly by the application of Article 1 universal, within the remit of the Contracting Parties to the ECHR [4].

In short, the legality of deportation and or removal practices within the confines of the rule of law and minimum procedural safeguards as encapsulated by international human rights law, will be engaged. The putative question is whether the United Kingdom complies with its treaty 
obligations under International Human Rights law in the expulsion of migrants? Consistent with this is argument that the United Kingdom has the reputation of operating a complex set of immigration laws in the form of laws, rules, policies, regulations, guidelines, discretionary powers, prerogatives and orders. The issue is that the prevalence of a vast body of case law adds to the already difficult burden of operating these complex legislations, to the extent that keeping track of the law and practices have become a superhuman task [5]. As Edwards recounts, "the constantly changing laws and regulations lead much to confusion and lack of accountability" [6]. This could be interpreted to mean that, the more the 'laws', the easier it becomes to achieve expulsion, the more complex the laws, the easier it becomes to attract violation. Vehemently put, the more the laws are made, the more the atmosphere of expulsion is created. It is therefore queried whether deportation laws as they stand may have been contrived to enhance deportability or removability.

It is further argued that the ever increasing and shifting pattern of deportation laws (some of which are retroactive) appears to violate the basic principles of human rights norms. This is heightened by the fact that these laws are either discretionary or couched in rigid terms leaving less chance for compassionate considerations even in the light of unclear judicial interpretation given to some of these deportation laws. Discussions will revolve around the appeal procedures and the attendant issues of certification and its multiplier effects. The dichotomy between 'immigration decision' and 'non immigration decision' will be engaged in order to ascertain the complexities of this distinction and its effect on deportation or removal. And this raises fundamental questions as to whether expulsion practices as they exist are uncontrolled and a naked display of State power.

As written in Joel 3:10 of the Holy Bible, where it was stated 'beat your plowshares into swords and your pruninghooks into spears- let the weak say, I am strong' the euphemism or allegorical position is that the law can be used as an instrument of oppression in such a subtle way that it might take much more than a critical mind to identify. In his commentary on this, Ellicott had stated 'when the contest was over, and the victory of the Lord achieved, Micah foresaw the reversal of this order: the weapons of offence were once more to resume their peaceful character, inadvertently meaning that nation shall not lift up sword against nation, neither shall they learn war anymore'[7].

\section{2. 'Immigration Decision' Certification and the Appeal Process}

'Immigration decision', certification and the appeal process, it is contended, are vehicles to the contrivance of deportability. The argument is that through the instrumentality of the laws, albeit the interpretation given to the concept of 'immigration decision' and the explicit consequences of certification of decisions, deportation of migrants is heightened and sustained. Therefore, the configuration of the appeals system in immigration matters appears to be contrived in a manner that suggests the enhancement of deportation.

The legislative framework for the appeals system is located at Part 5 of the 2002 Act, which has as one of its central aims the provisions for a one-stop appeal with the intention that all relevant issues can be considered at one appeal [8]. The 2002 Act at section 82 (2) lists those decisions that are defined as 'immigration decisions' [9]. These are:

In this Part "immigration decision" means-(a) refusal of leave to enter the United Kingdom, (b) refusal of entry clearance,(c) refusal of a certificate of entitlement under section 10 of this Act, (d) refusal to vary a person's leave to enter or remain in the United Kingdom if the result of the refusal is that the person has no leave to enter or remain, (e) variation of a person's leave to enter or remain in the United Kingdom if when the variation takes effect the person has no leave to enter or remain, (f) revocation under section 76 of this Act of indefinite leave to enter or remain in the United Kingdom, $(\mathrm{g})$ a decision that a person is to be removed from the United Kingdom by way of directions under section 10 (1) (a), (b), (ba) or (c) of the Immigration and Asylum Act 1999 (removal of person unlawfully in United Kingdom), (h) a decision that an illegal entrant is to be removed from the United Kingdom by way of directions under paragraphs 8 to 10 of Schedule 2 to the Immigration Act 1971 (c. 77) (control of entry: removal), (i) a decision that a person is to be removed from the United Kingdom by way of directions given by virtue of paragraph 10A of that Schedule (family), (ia) a decision that a person is to be removed from the United Kingdom by way of directions under paragraph 12 (2) of Schedule 2 to the Immigration Act 1971.

Therefore, a refusal to vary a person's leave will be an immigration decision for the purposes of section 82 (1) of the 2002 Act [9] thus attracting a right of appeal under section 84 of the 2002 Act [9] if it results in the person having no leave to enter or remain. But where the applicant has no extant leave at the time of the application, any consequent refusal will not be an immigration decision [10]. The issue then is that the UK Visas and Immigration-an arm of the Home Office ostensibly decides application for leave to remain made by migrants with the consequence of grant or refusal of leave to remain [11]. When a decision is made and application refused, some attract rights of appeal and others do not. A decision to refuse leave is governed by section 82 (2) (d) of the 2002 Act within the meaning of immigration decision as highlighted above. The rights of appeal accorded to such persons in a given immigration decision will either be 'in country' or 'out country' [11]. The right of appeal which allows the person (appellant) to remain in the UK during the appeal process is referred as to as 'suspensive' meaning that such appeals suspends the removal of the migrant until the appeal has been fully disposed of. On the contrary, the right of appeal which does not allow the appellant to remain in the country during the appeal process which therefore does not suspend removal is referred to as 'non suspensive' [12]. Section 92 of the 2002 Act lists those immigration decisions, 
which confers a suspensive right of appeal [12]. This provision states: "Appeal from within United Kingdom: general' (1) A person may not appeal under section 82 (1) while he is in the United Kingdom unless his appeal is of a kind to which this section applies. (2) This section applies to an appeal against an immigration decision of a kind specified in section 82 (2) (c), (d), (e), (f) and (j)'. Therefore a decision that a person is to be removed by way of directions under section 10 of the 1999 Act does not allow for an in-country right of appeal because section 82 (2) (g) of the 2002 Act is not listed as immigration decisions with an in-country right of appeal under section 92 (2) of the 2002 Act.

In essence, a refusal of an application made by an irregular migrant is not an immigration decision because he had no leave when the application was made, and the migrant as a consequence is not entitled to right of appeal leading to enforcement action for removal from the UK. The First Tier Immigration Tribunal in corroboration of the above further held that a decision to refuse leave is not an immigration decision if the applicant had no remaining leave at the time the application was submitted [13].

The argument is that the dichotomy between an 'immigration decision' and 'non-immigration decision' is a false one as it is probably anchored with the apparent intention of achieving expulsion of migrants from the UK in an ostensibly hostile environment. It is curious that the irregular migrant who makes an application (usually by payment of a fee) to the Home Office to regularize his stay which was eventually refused will not be accorded a right of appeal simply because, the State sees such applications as not befitting of a right of appeal. It is therefore difficult to justify the rationale to deny a right of appeal to a migrant or to dichotomize between an immigration decision and a nonimmigration decision in the light of the immigration rules. The reasoning is that the old 14-year long residence rule enables irregular migrants, overstayers or those with breach of conditions to regularize their immigration status and obtain indefinite leave to remain if they remain in the country for 14 years but now 20 years [14]. This accounted for the comment by the Court of Appeal when it stated that the rules operate in the nature of an amnesty because it does not require the migrant to have lawful residence during the period [15]. The court reasoned that the raison d'être of the rule was to enable such a person to regularize their stay, therefore holding illegality [irregularity] against them and to refuse leave was a destruction of the point of the rule [15].

It is therefore puzzling that when such rights of appeal are granted to the irregular migrant-overstayer under section 10 of the 1999 Act-administrative removal, such do not attract an in-country right of appeal and therefore not suspensive unless the migrant made an asylum or human rights claim by virtue of section 92 (4) (a) of the 2002 Act or that the migrant is an EEA national or family member who claims that the decision is a breach of his treaty rights [16]. Section 94 of the 2002 Act provides:

'Appeal from within United Kingdom: unfounded human rights or asylum claim' (1) This section applies to an appeal under section 82 (1) where the appellant has made an asylum claim or a human rights claim (or both). (1A) A person may not bring an appeal against an immigration decision of a kind specified unfounded. (2) A person may not bring an appeal to which this section applies in reliance on section 92 (4) (a) if the Secretary of State certifies that the claim or claims mentioned in subsection (1) is or are clearly unfounded. (3) If the Secretary of State is satisfied that an asylum claimant or human rights claimant is entitled to reside in a State listed in subsection (4) he shall certify the claim under subsection (2) unless satisfied that it is not clearly unfounded in section 82 (2) (c), (d) or (e) in reliance on section 92 (2) if the Secretary of State certifies that the claim or claims mentioned in subsection (1) above is or are clearly; Section 96 of the 2002 Act-Earlier right of appeal (1) An appeal under section 82 (1) against an immigration decision ("the new decision") in respect of a person may not be brought if the Secretary of State or an immigration officer certifies - (a) that the person was notified of a right of appeal under that section against another immigration decision ("the old decision") (whether or not an appeal was brought and whether or not any appeal brought has been determined) [...]' [16].

However, the right to make an in-country appeal, which suspends removal, can be achieved only if the Secretary of State did not certify (certification) the migrant's claim as clearly unfounded by virtue of section 94 or 96 of the 2002 Act [16]. When section 94 is applied, the consequence is that the migrant will only be entitled to an appeal of the decision while out of the country but when section 96 is applied, no right of appeal is totally allowed. The issue of immigration decision and suspensivity appears to be a contrivance to increase deportation targets, which as we argue is a recurring decimal in deportation practices of a liberal democracy.

As Craig and Fletcher observed, an applicant under section 96 of the 2002 Act is prevented from bringing an appeal against refusal of an asylum claim, which could have been brought earlier but was not and they argue that nonsuspensive appeals effectively deny the appeal right given that access issues are practically insuperable when claiming from abroad with the only availing remedy of a judicial review [17]. In addition, the several time lines for the submission of appeals and attempts aimed at curtailing access to higher courts in statutory and judicial review applications have been proactive. This proactivity and consistency in the gradual but ostensible elimination of the right of appeal is an ingredient of a wholesale approach to restructuring of the appeal process for the singular purpose of achieving a set objective- deportation [17].

In furtherance of that manifestation of intention, an anxious scrutiny can equally be taken of the recent Home Secretary's statement where she stated that the government would use legislation to remove the several layers of appeal available to foreign nationals subject to deportation [18]. The Immigration Act of 2014 continues the manifestation of this policy [18]. The Act now further restricts the right of appeal of migrants with a view to achieving deportation stating that First Tier Tribunal must not consider a 'new matter' unless the Secretary 
of State has given consent to the Tribunal to do so.

Furthermore, the 2014 Act allows the Secretary of State to certify a claim prior to appeal proceedings, during the course of the appeal or after exhaustion of the appeal [18]. At section 17 of the Act with the heading "94B (2) Appeal from within the United Kingdom: certification of human rights claims made by persons liable to deportation", paragraph 2 states that the Secretary of State may certify a claim if the Secretary of State considers that despite the appeal process not having begun or not having been exhausted, removal of a person can continue provided it is not unlawful under section 6 of the Human Rights Act 1998. The implication is that while during the appeal proceedings, the Secretary of State may certify a matter as clearly unfounded, which will then bring an end to the legal challenge mounted against deportation with the effect that enforcement action would proceed. In short, the Act has been referred to as aiming to create a 'hostile environment' for many migrants in the UK, fuelled further by its movement at breakneck speed through the House of Commons without allowing MPs to properly scrutinize its implications. The Labour party was reported to have unsuccessfully challenged restrictions on the right to appeal amongst others [19]. As Yeo stated, aside of the new Immigration Act's removal of the right of appeal rights against decisions made under the Immigration Rules, it also removes the 'not in accordance with the law' ground of appeal [20].

In effect, with the advent of the immigration Act 2014, the use of immigration tribunals to correct administrative decisions which has profound effective on people's lives will be limited if not non existence leading to a return to the pre 1993 era when no refugee appeals were allowed and until 1998 when human rights appeals started [20].

Despite the above concerns, evidence suggests that it is apparent that the Home Office has adopted the 'deport first, appeal second' approach. The then Home Secretary, Theresa May (who later became the Prime Minister) at the Tory Party conference in Manchester in 2013 was quoted as saying that Britain's immigration system is like a "never-ending game of snakes and ladders" and vowed to end the culture of endless appeals [21]. She stated that the foreign criminals, terrorists and illegal immigrants will be kicked out of Britain before they get the chance to claim that their human rights are being breached. In order to achieve this, she stated that the number of grounds on which an appeal can be lodged will be reduced from the current 17 to 4 just four after the fiasco of the deportation of Abu Qatada who was deported after a 12-year legal battle [21]. True to that, and as part of the hostile environment, the Immigration Act 2014 pursuant to that, reduced the right of appeal and extended the number of nonsuspensive appeals with the objective of 'deport foreign criminals first and hear their appeals later' where the Home Office claims that there will be no risk of serious and irreversible harm upon deportation. In her words the then Home Secretary stated:

The Abu Qatada case proved that we need a dramatic change in our human rights law. We're going to cut the number of appeal rights, extend cases where we deport first and hear the appeal later, and use primary legislation to make sure judges interpret the "right to a family life" properly [21].

Chorley reports that in the light of this case, the Home Secretary was stated to have said that the Home Office is poised to crackdown to more than halve the astonishing 68,000 cases lodged against the Government while condemning the ECtHR for allowing such cases and supported by the then Prime Minister David Cameron who condemned the ECtHR and threatened the United Kingdom's complete withdrawal from the ECHR. He asserted at that time that in future, the Home Office will be empowered to throw people out of the country as soon as their case has been decided by the Government only with an out of country appeal right [21].

Further to the removal of right of appeals and suspensivity is the issue of deferral of removal decisions. The argument here is that the deferral of the issuance of a removal decision, which would have attracted a right of appeal, is in itself a contrivance of contrivance of deportability. In Mirza \& Ors v SSHD [22] the claimants argued that the Home Secretary should have issued removal directions under section 10 of the 1999 Act to enable them appeal and raise further arguments as set out in the then paragraph $395 \mathrm{C}$ of the Immigration Rules and exercise discretion on the basis of them [23]. The Court of Appeal ruled that unjustified deferral of a decision on removal is contrary to law because it makes it impossible to justify the disruption of family and private life emphasizing that there is no legal justification for routinely putting removal on hold or for indefinite period [24]. The reasoning is that if the State has an interest in not multiplying administrative proceedings and appeals, then there is a correlative duty of fairness towards individuals whose lives are on hold, and who may well be committing a criminal offence by their mere presence while awaiting an appealable decision [22].

\subsection{Certification}

Simply put, the meaning of certification is that if an asylum and or human rights claim is certified as 'clearly unfounded' under section 94, the applicant cannot appeal whilst in the United Kingdom. This applies to decisions listed in section 82 (2) (c), (d), and (e) under section 92 (2) of the 2002 Act.

Certification as argued earlier is a vehicle for the contrivance of deportability. Section 94 of the 2002 Act applies to all appeals made under Part 5 of the 2002 Act and provides a certification process which removes the right for an in-country appeal on certain asylum and or human rights claims consistent with section 84 (1) of the 2002 Act. The Home Office Policy document on certification advises its officials to ensure that the power can only be used in cases where the claim is considered to be 'clearly unfounded' and strict criteria must be met before certifying [25].

In order to certify a claim as 'clearly unfounded' the Home Secretary acting through the case owner (designated official) needs to be satisfied that the claim cannot, on any legitimate view, succeed. In $R v$ SSHD ex $p$ Thangarasa \& Yogathas [26] 
the House of Lords defined 'clearly unfounded' as a manifestly unfounded claim, which is so clearly without substance that it is bound to fail. The court added that, it is possible for a claim to be manifestly unfounded even if it takes more than a cursory look at the evidence to come to a view that there is nothing of substance in it. In $Z L$ and $V L v S S H D$ [27], the Court of Appeal gave further guidance on how to approach consideration of clearly unfounded cases. The court held that the Home Secretary should consider the factual substance and detail of the claim; consider how it stands with the known background data; consider in the round whether it is capable of belief; consider whether some part is capable of belief; consider whether, if eventually believed in whole or part, it is capable of coming within the convention.

In addition, when a question of credibility is turned on by certification, the court cautioned:

Where an appellant's case does turn on credibility, the fact that the interviewer does not believe the appellant will not, of itself, justify a finding that a claim is clearly unfounded $[. .$. Only where the interviewing officer is satisfied that nobody could believe the appellant's story will it be appropriate to certify the claim as clearly unfounded on the ground of lack of credibility alone $[27 ; 60]$.

Furthermore in $A A$ (Iraq) $v$ SSHD [28] it was held that when the issue of certification is turned on with the claim being 'clearly unfounded' the court's role in such cases is to apply normal judicial review principles, in addition to the 'anxious scrutiny' requirement [29]. Therefore, the test is whether the Secretary of State's decision to certify was irrational, and if it was, then it was not 'clearly unfounded'.

It could therefore be argued that the aim of certification is to create a safe passage to deportation where the migrant would have been removed from the country before appealing the decision to against him. By contriving deportation through certification, the State aims to achieve a set objective through its laws and policies. If it is difficult to succeed in an in-country appeal involving deportation and or removal, it follows that it may be more difficult to succeed once the migrant has been deported from the State. Bail for Immigration Detainees (BID) had reported that legal aid in the United Kingdom, is in itself is a mirage as the 'the availability of legal aid for immigration exists only in name' whereas the cost of legal representation poses an obstacle for a deportee, unarguably [30]. This is further to the argument that, given the vulnerability and impecunious status of some migrants subject to deportation even while possessing incountry right of appeal, access to justice may be a mirage, as they may not afford legal representation. Without proper legal representation in the light of complex immigration laws, success may be far fetched.

In addition, certification is antithetical to equality of arms and the right to effective participation is compromised as the migrant would have been removed in a certified case and will be left with the option of appeal from outside the United Kingdom. In Neumeister v Austria [31], the court harped on the importance of equality of arms stating that there is need for a fair balance between opportunities afforded to parties in litigation. As the ECtHR made it clear in Fischer v Austria [32], the requirement of equality of arms can be breached by merely procedural inequality without the need for quantifiable unfairness. It follows that if the migrant has been removed, he would have been placed in a substantial disadvantaged position against the State, as the migrant may not have been given reasonable opportunity to present his case- a right of 'reasonable opportunity' [33].

Certification analytically espoused, elicits the concepts of irrationality (unreasonableness). The level of training of the case owner is important if a matter should be certified in the first place. As the House of Lords guided in $Z L$ and $V L$ above, if the migrant's case is capable of belief wholly or in part whether or not the case owner believes it, then there should be no certification. Irrationality invokes morality where Lord Diplock stated that this 'applies to a decision so outrageous and in defiance of logic or accepted moral standards that no sensible person who had applied his mind to the question to be decided could have arrived at it' [34]. The Policy document on certification advises its case owners to note that certification under section 94 are assessed at their highest and are only certified when they are bound to fail, but whether this is followed in practice is a different matter as decisions may be taken for improper purpose given that there are no safeguards in place [35].

\subsection{Certification and 'Immigration Decisions' Analysed}

Certification in concert with the false dichotomy of 'immigration decision' turns on the issue of lack of effective remedy contrary to Article 13 ECHR 1950 [36]. By certifying decisions, which restricts in-country rights of appeal together with the concept of 'immigration decision', the rights of migrants have been affected. In De Souza Ribeiro v. France [37], the applicant alleged a violation of Article 8 of the Convention, read alone and in conjunction with Article 13 in particular, given that he had had no possibility of challenging the lawfulness of a removal order prior to its execution. The court stated:

Where a complaint concerns allegations that the person's expulsion would expose him to a real risk of suffering treatment contrary to Article 3 of the Convention, in view of the importance the Court attaches to that provision and given the irreversible nature of the harm that might occur if the risk of torture or ill-treatment alleged materialized, the effectiveness of the remedy for the purposes of Article 13 requires imperatively that the complaint be subject to close scrutiny by a national authority [...] independent and rigorous scrutiny of a claim that there exist substantial grounds for fearing a real risk of treatment contrary to Article $3[\ldots]$ and reasonable promptness [...] In such a case, effectiveness also requires that the person concerned should have access to a remedy with automatic suspensive effect [...] Lastly, the requirement that a remedy should have automatic suspensive effect has been confirmed for complaints under Article 4 of Protocol No. 4 [37, 38].

The court continued:

By contrast, where expulsions are challenged on the basis of alleged interference with private and family life, it is not 
imperative, in order for a remedy to be effective, that it should have automatic suspensive effect. Nevertheless, in immigration matters, where there is an arguable claim that expulsion threatens to interfere with the alien's right to respect for his private and family life, Article 13 in conjunction with Article 8 of the Convention requires that States must make available to the individual concerned the effective possibility of challenging the deportation or refusalof-residence order and of having the relevant issues examined with sufficient procedural safeguards and thoroughness by an appropriate domestic forum offering adequate guarantees of independence and impartiality [37].

The court emphasized that even though States are afforded some discretion as to the manner in which they conform to their obligations under Article 13 of the Convention, that discretion must not result in the practical denial of the minimum procedural safeguards needed to protect the migrant against arbitrary expulsion. In De Souza, the applicant was deported within 50 minutes of lodging a judicial review application before the administrative court. The Grand Chamber's criticism was that the administrative court judge was not given the opportunity to decide whether to suspend his deportation or not. So, there was no judicial scrutiny at all [39]. In De Souza's case as in many expulsion enforcements, the haste with which the removal order was executed had the effect of rendering the available remedies ineffective in practice and therefore inaccessible. While the Court is aware of the importance of swift access to a remedy, speed should not go so far as to constitute an obstacle or unjustified hindrance to making use of it or take priority over its practical effectiveness [37].

However, even though it appears that the court drew a distinction between Art 3 ECHR right-an absolute right therefore attracting automatic suspensive effect and Article 8 ECHR rights being a qualified right that may not attract automatic suspensive effects, but they must conform to sufficient procedural safeguards and thoroughness. This, in our view, does not involve certification or false distinctions between one application or another for variation of leave without guarantees of independence and impartiality.

Quite recently, the Court in AS (India) v Home Office [40] was called upon to rule on the failure of the Home Office to consider further submissions in a matter involving overstaying under paragraph 353 of the Immigration Rules which states:

'when a human rights or protection claim has been refused or withdrawn or treated as withdrawn under paragraph 333C of these Rules and any appeal relating to that claim is no longer pending, the decision maker will consider any further submissions and, if rejected, will then determine whether they amount to a fresh claim. The submissions will amount to a fresh claim if they are significantly different from the material that has previously been considered. The submissions will only be significantly different if the content: (i) had not already been considered; and (ii) taken together with the previously considered material, created a realistic prospect of success, notwithstanding its rejection. This paragraph does not apply to claims made overseas'.
In interpreting this provision, the Court in $A S$ (India) supra held that the Respondent's error in failing to give any proper consideration to the new documentation provided in support of the petitioner's fresh claim was a material error. Flowing from the above, it is submitted that applying paragraph 353 [41] by the Respondent without considering the merits of the application was simply injurious to the petitioner's claim.

More importantly, the Court of Appeal had to rule on a matter where certification was applied in a human rights claim. The Court in SP (Albania) v SSHD [42] clarified that if there was 'material which was capable of being objectively well-founded and sufficient to establish a claim, but which was not accepted by the Secretary of State, then an opportunity to have that evidence tested before a judge of the First Tier Tribunal should be given and certification was inappropriate. This means that the Court recognised the need for testing of evidence before an independent adjudicator which the Respondent's caseworker would have ignored even as it concerns issues revolving around the right to private and family life established in the United Kingdom by the applicant and partner.

In a recent case, the issue of denial or right of appeal in a domestic violence case came live. This concerns where a human rights claim has been made such as this was engaged recently by the High Court. In the Queen (on the application of AT v SSHD) 2017 EWHC 2589 decided on 18 October 2017, Hon Mr Justice Kerr held thus:

The 2002 Act was amended accordingly, but there was still a right of appeal (see section 82 (1) (b), as amended from 20 October 2014) against a decision to refuse a human rights claim, as defined in section 113. Under section 84 (2), as amended from 20 October 2014, such an appeal has to be 'brought on the ground that the decision is unlawful under section 6 of the Human Rights Act 1998'.

\subsection{Certification Under Section 94B, Art 8 and Irreversible Harm}

It is unarguable to posit that Article $8 \mathrm{ECHR}$ (the right to private and family life) has a procedural aspect and that the Secretary of the State cannot lawfully certify a human rights claim (as in deportation cases) under section 94B if the requirement to appeal from outside the UK means that the person cannot access a fair appeal process from outside the United Kingdom. The case of Kiarie \& Byndloss $v$ SSHD [43] is instructive where the Court of Appeal has stated that the correct test is whether removal for the duration of the appeal will breach the appellant's human rights, not whether it will cause serious irreversible harm. In the same case that went further to the Supreme Court (published on the 14 June 2017), Kiarie \& Byndloss v SSHD [43], the Supreme Court came heavily against certification and concluded that it will be manifestly unfair to allow an applicant to present evidence from abroad with limited resources which ultimately might make it difficult for him to successfully argue his appeal.

In short, in Kiarie \& Byndloss, the Supreme Court famously held that out-of-country appeals may be unlawful when appellants could not effectively appeal against the decision from outside the UK, including difficulties in 
securing legal representation and giving evidence. The court clarified that if an appeal from abroad will not be effective, then the public interest in removal would be outweighed and an application should not be certified.

\subsection{Certification and the Reasonable Prospect of Success}

In refusing applications for leave to remain, the decision sometimes relies on paragraph 353 of the Immigration Rules especially when there has been a repeat application. In doing so, the decision maker makes the claim that the applicant's claim does not create a realistic prospect of success and on the basis of that, will refuse the claim. This paper on the contrary and based on the above analysis argues that consideration under paragraph 353 is out of context with reality and should not stand. It is submitted that it should be left to the courts to determine what creates a prospect of success in a human rights claim rather than the decision maker who considers the migrant's application. In a recent case of SS $v$ SSHD [44], the Court held that it was Wednesbury unreasonable to refuse to accept the applicant's submission as forming a fresh claim with a reasonable prospect of success at the First Tier Tribunal, disparaging as it did, the issue of strong grounds or cogent evidence.

\section{Conclusion}

This research has shown that through the instrumentality of the laws, albeit the interpretation given to the concept of 'immigration decision' and the explicit consequences of certification of decisions, deportation of migrants is heightened and sustained. Therefore, the configuration of the appeals system in immigration matters appears to be contrived in a manner that suggests the enhancement of expulsion of migrants.

Certification analytically espoused, elicits the concepts of irrationality (unreasonableness) and certification in concert with the false dichotomy of 'immigration decision' turns on the issue of lack of effective remedy contrary to Article 13 ECHR 1950. Although, States are afforded some discretion as to the manner in which they conform to their obligations under Article 13 of the Convention, that discretion must not result in the practical denial of the minimum procedural safeguards needed to protect the migrant against arbitrary expulsion. This proactivity and consistency in the gradual but ostensible elimination of the right of appeal is an ingredient of a wholesale approach to restructuring of the appeal process for the singular purpose of achieving a set objective-expulsion.

Furthermore, it has been shown by analysis that certification is antithetical to equality of arms and the right to effective participation is compromised as the migrant would have been removed in a certified case and will be left with the option of appeal from outside the United Kingdom.

\section{References}

[1] Alice Bloch and Liza Schuster, 'At the extremes of exclusion: Deportation, detention and dispersal’ (2005) 28.
[2] C Dauvergne, 'Sovereignty, Migration and the Rule of Law in Global Times' (2004) 67 Modern Law Review 588, 589; C Schreuer, 'The Waning of the Sovereign State: Towards a New Paradigm for International Law?' (1993) 4 European Journal of International Law 447.

[3] Ian Bryan and Peter Langford, 'Impediments to the Expulsion of Non-Nationals: Substance and Coherence in Procedural Protection under the European Convention on Human Rights' (2010) 79 Nordic Journal of Law 457, 459; Alison Harvey, 'Expulsion and Exclusion' (2007) 21 (3) Journal of Immigration, Asylum and Nationality Law, 208.

[4] Convention for the Protection of Human Rights and Fundamental Freedoms (European Convention on Human Rights, as amended) (ECHR) 1950, CETS no 005, Article 1 of the ECHR provides: 'The High Contracting Parties shall secure to everyone within their jurisdiction the rights and freedoms defined in Section I of this Convention'; It is important to mention that member states of the European Union are also members of the Council of Europe where each is a signatory. See Council of Europe Parliamentary Assembly Resolution 1031 $<\mathrm{http}: / /$ assembly.coe.int/Main.asp?link=/Documents/AdoptedText/t a94/ERES1031.htm> accessed 11 July 2018.

[5] Ian Macdonald and Ronan Toal, Macdonald's Immigration Law \& Practice ( ${ }^{\text {st }}$ Supp, $7^{\text {th }}$ edn, LexisNexis 2009) 1.

[6] Emmanuela Paoletti, 'Deportation, non-deportability and ideas of membership' (2010) RSC Working Paper Series 65/2010, 15.

[7] Ellicott's Commentary for English Readers< https://biblehub.com/commentaries/joel/3-10.htm > accessed 18 January 2020.

[8] See section 120 of the Nationality, Immigration and Asylum Act 2002 under the caption 'Requirement to state additional grounds for application'.

[9] Nationality, Immigration and Asylum Act 2002, s 82 (2).

[10] Kerry Ann Veronica \& Daley Murdock v SSHD [2011] EWCA Civ 161.

[11] Home Office UK Border Agency, 'UK Border Agency's transition to Home Office' http://www.ukba.homeoffice.gov.uk/sitecontent/newsarticles/ 2013/may/11-transition accessed 04 December 2019.

[12] UK Border Agency, 'Enforcement Instruction and Guidance' (Chapter 20-Appeals) http://www.ukba.homeoffice.gov.uk/sitecontent/documents/po licyandlaw/enforcement/oemsectiond/Appeals?view=Binary accessed 05 December 2013.

[13] SA Pakistan [2007] UKAIT 00083-.

[14] The new rule is now located at paragraph 276ADE (1) (iii) of the Immigration Rules, See Statement of Changes in Immigration Rules HC 194. Note the old rule at paragraph $276 \mathrm{~B}$ of the Immigration Rule HC 395. The new rules which came into effect on or after on or after 9 July 2012 now require 20 years long (unlawful) residence to obtain indefinite leave to remain in addition to certain conditions such as good conduct and no criminal convictions.

[15] ZH (Bangladesh) v SSHD [2009] EWCA Civ 8, the Court stated 'The 14-year rule set out in Rule 276B (i) (b) is thus specifically directed to people who have managed to stay here for 14 years or more without lawful authority. It is in effect an amnesty clause'. 
46 Cosmas Ukachukwu Ikegwuruka and Linus Chukwuemeka Okere: 'Beat Your Plowshares into Swords and Your Pruninghooks into Spears': A Contextual Critique of Expulsion Decisions and Appeal Rights in the United Kingdom

[16] Nationality, Immigration and Asylum Act 2002, s 92 (4).

[17] Sarah Craig and Maria Fletcher, 'The Supervision of Immigration and Asylum Appeals in the UK-Taking Stock' (2012) 0 International Journal of Refugee Law 1, 12.

[18] The Immigration Act 2014, s 15 \& s 15 (5) (6) (b) 'New matter' means a matter that the Secretary of State has not considered, note that the Act under 'Right of Appeal to the First Tier Tribunal' amends the grounds of appeal as stated in Section 84 of the Nationality, Immigration and Asylum Act 2002. Cf. this provision with section 94 of the Nationality, Immigration and Asylum Act 2002 where certification is not permissible during the appeal process.

[19] Ruth Grove-White, 'The Conservative amendment throwing a spanner in the works for the Immigration Bill' Migrant Right Network (02 December 2019) http://www.migrantsrights.org.uk/blog/2013/12/conservativeamendment-throwing-spanner-works-immigration-

bill?utm_source $=$ Migrants + Rights + News\&utm_campaign $=$ ea 27389ddf-MRN News 2-12-

2013\&utm_medium $=$ email\&utm_term $=0 \_1084 \mathrm{a} 7080 \mathrm{c}$ ea27389ddf-217215973 accessed 06 December 2019.

[20] Colin Yeo, 'Appeals and the Immigration Bill' http://www.freemovement.org.uk/2013/10/31/immigrationappeals-judicial-review-immigration-bill/ accessed 10 December 2018. The Immigration and Asylum Appeals Act 1993 introduced in-country asylum appeals, note that Yeo was commenting when the Act was still a Bill.

[21] Matt Chorley, James Slack and James Chapman, 'Immigration system is like a never-ending game of snakes and ladders: Theresa May vows to kick out illegal migrants BEFORE they get chance to appeal' MailOnline (London 30 September 2013) <http://www.dailymail.co.uk/news/article2438130/Theresa-May-Ill-kick-illegal-migrants-BEFOREchance-appeal.html $>$ accessed 10 October 2017.

[22] Mirza \& Ors $v$ SSHD [2011] EWCA Civ 159.

[23] EO (Turkey) [2007] UKAIT 00062.

[24] Cf. TE (Eritrea) v SSHD [2009] EWCA Civ 174 which held that it may in some cases be unfair and hence unlawful for the Home Secretary not to do so, but not that she is obliged in all cases to do so.

[25] See Home Office, 'Non-Suspensive Appeals (NSA) Certification under Section 94 of the NIA Act 2002' $<\mathrm{http} / / /$ www.ukba.homeoffice.gov.uk/sitecontent/documents/p olicyandlaw/asylumprocessguidance/specialcases/guidance/ce rtificationundersection94.pdf?view=Binary $>$ accessed 18 January 2020.

[26] R v SSHD ex p Thangarasa \& Yogathas [2002] UKHL 36.

[27] ZL and VL v SSHD [2003] EWCA Civ 25.

[28] AA (Iraq) v SSHD [2012] EWCA Civ 23 [92-94].
[29] ZT (Kosovo) v SSHD [2009] UKHL 6.

[30] Bail for Immigration Detainees (BID), 'Out of sight, out of mind: experiences of immigration detention in the UK (July 2009) 34-44.

[31] Neumeister v Austria (1968) 1 EHRR 91, para 24.

[32] Fischer v Austria App No 33382/96 (ECtHR, 06 January 2000) paras 33, 44.

[33] Dombo Beheer BV v Netherlands (1993) 18 EHRR 213.

[34] Council of Civil Service Unions v Minister for the Civil Service [1985] AC 374 [410].

[35] Congreve v Home Office [1976] QB 629 [662]; Porter v Magill [2001] UKHL 673 on improper purpose that includes malice, threats or personal dishonesty on part of the officials making the decision- the Court has held that the exercise of a power for improper purpose is invalid.

[36] Convention for the Protection of Human Rights and Fundamental Freedoms (European Convention on Human Rights, as amended) (ECHR) 1950, CETS no 005, Article 13 ECHR 1950 states 'Everyone whose rights and freedoms as set forth in this Convention are violated shall have an effective remedy before a national authority notwithstanding that the violation has been committed by persons acting in an official capacity'.

[37] De Souza Ribeiro v. France App no 22689/07 (ECtHR, 13 December 2012) Cf. M. and Others v. Bulgaria App no 41416/08 (ECtHR, 26 July 2011), paras 115-116 concerning the illegality of enforcing a defective deportation order and $\mathrm{Al}$ Nashif v. Bulgaria App no. 50963/99 (ECtHR, 20 September 2002) para 142 concerning unlawful deportation and lack of effective remedy.

[38] De Souza Ribeiro, para 82; Cf. Hirsi Jamaa and Others v. Italy App no 27765/09 (ECtHR, 23 February 2012), para 200 where the court ruled that if anything, suspensive effect should also apply to cases in which a State Party decides to remove an alien to a country where there are substantial grounds for believing that he or she faces a risk of that nature.

[39] Adam Wagner, 'Deport first, appeal second' $<$ http://ukhumanrightsblog.com/2013/01/06/deport-firstappeal-second/ > accessed 10 December 2013.

[40] AS (India) v Home Office [2019] CSOH 43.

[41] Paragraph 353 of the Immigration Rules.

[42] SP (Albania) v SSHD [2019] EWCA Civ 951.

[43] Kiarie \& Byndloss v SSHD [2015] EWCA Civ 1020; Kiarie \& Byndloss v SSHD [2017] UKSC 42.

[44] SS v SSHD [2019] EWHC 1402 (Admin). 